\title{
Fludeoxyglucose F-18
}

National Cancer Institute

\section{Source}

National Cancer Institute. Fludeoxyglucose F-18. NCI Thesaurus. Code C964.

A positron-emitting radiopharmaceutical containing radioactive 2-deoxy-2-[18F] fluoro-

D-glucose. With similar cell uptake as glucose (high in tumor cells), fludeoxyg lucose F 18 is not dephosphorylated and further metabolized. (NCI04) 